\title{
VOJAŠKOMEDICINSKA OBVEŠČEVALNA DEJAVNOST Z OMEJENIMI VIRI NA PRIMERU MAJHNIH DRŽAV
}

\author{
MILITARY MEDICAL INTELLIGENCE WITH LIMITED \\ RESOURCES IN THE CASE OF SMALL COUNTRIES
}

Povzetek Slovenska vojska poleg nacionalne obrambe opravlja naloge v mednarodnih operacijah in na misijah v zahtevnih podnebnih in geografskih razmerah zunaj območja držav članic Nata in EU. Zavezniške sile, ki opravljajo svoje poslanstvo na ozemljih zunaj Natovega območja, so lahko izpostavljene različnim dejavnikom tveganja, ki vplivajo na njihovo zdravje. Za njihovo ustrezno zdravstveno zaščito je treba sprejeti in izvajati učinkovit program, ki naj bo namenjen tako zdravstvenemu osebju kot poveljnikom. Strokovno zdravstveno osebje pridobiva zdravstvene podatke, na primer ocenjuje okoljske in zdravstvene vire ogrožanja, prepozna tveganja in izdela analizo groženj, ter jih vključuje v upravljanje tveganj. MEDINT ima pomembno vlogo $\mathrm{v}$ razmerju med zdravstvenim sistemom in krovno obveščevalno dejavnostjo, uporablja zakonitosti njenega obveščevalnega ciklusa, saj se na nekaterih stopnjah obveščevalni ciklus MEDINT vključuje v obveščevalni ciklus krovne obveščevalne dejavnosti. Končni obveščevalni proizvod MEDINT, ki temelji na oceni zdravstvene ogroženosti, podpira poveljnikov namen in operacijo.

Ključne besede

Abstract

\section{MEDINT, obveščevalna dejavnost, vrednotenje medicinsko-geografskega prostora, Slovenska vojska.}

In addition to providing for national defence, the Slovenian Armed Forces perform tasks in demanding climatic and geographical conditions in international operations and missions outside the territory of NATO and EU Member States. Allied forces performing their mission in the territories outside the NATO area may be exposed to various threats that affect their health. For the protection of the forces' health, it is necessary to adopt and implement an effective program, which should be aimed, both, at healthcare personnel as well as commanders. Professional medical staff obtains medical data, assesses environmental and medical threats, identifies the risks, carries 
out threat analysis and implements them in risk management. Medical intelligence (MEDINT) plays an important role in the relation between the health system and intelligence activities. It also uses the intelligence cycle to ensure that all available information for making assessments is processed. To be fully efficient MEDINT requires the cooperation of experts from different natural science disciplines (medical, scientific or bio-engineering). The final MEDINT product based on the health threat assessment supports the commander's intent and the operation as such.

Key words MEDINT, intelligence, evaluation of medico-geographical environment, Slovenian Armed Forces.

Uvod Vojaška zgodovina nas uči, da so se mnoge bitke končale z velikimi izgubami vojakov, predvsem zaradi nepoznavanja nalezljivih bolezni, nepravilne zdravstvene zaščite sile in nepoznavanja škodljivih vplivov okolja na območju delovanja. Slovenska vojska (SV) kot obrambna sila Republike Slovenije je med operacijami kriznega odzivanja na geografskem območju, ki ni del ozemlja članic Nata, izpostavljena različnim dejavnikom tveganja za zdravje.

»Vnaprejšnja informacija omogoča modrim vladarjem in uglednim generalom, da napredujejo in osvajajo, prinese jim uspeh, ki jim ga številčnost ne more."

(Sunzi, 2009, str. 145)

Za zagotavljanje zdravstvene zaščite sile ima zelo pomembno vlogo medicinska obveščevalna dejavnost (Medical Intelligence - MEDINT), ki je v strukturi podzvrst krovne obveščevalne dejavnosti. V MEDINT sodelujejo strokovnjaki s področja naravoslovnih znanosti, ki pridobivajo medicinske, bioznanstvene, epidemiološke in okoljske podatke, pomembne za zdravje ljudi in živali.

Slovenska vojska sodeluje $\mathrm{v}$ mednarodnih operacijah in na misijah (MOM) tudi v okoljih, ki so z medicinskega in geoprostorskega vidika slabo poznana. Naloga MEDINT je pridobivanje podatkov o zdravstvenih in okoljskih nevarnostih ter o zdravstvenih zmogljivostih in sposobnostih na območju delovanja. Pri pripravi načrta za zagotavljanje zdravstvene zaščite sile sta nujni civilno-vojaško in interdisciplinarno sodelovanje.

Predstavljena sta struktura in delovanje vojaškega zdravstva, prav tako je podan predlog modela MEDINT v SV, v katerem sta opredeljena uporabniško osredotočen model obveščevalnega procesa ter vključitev MEDINT v obveščevalni ciklus osrednje obveščevalne dejavnosti. Menimo, da je pri pripravi pripadnikov, ki sodelujejo v vojaških operacijah ekspedicijskega značaja, vloga MEDINT zelo pomembna. Pri tem ne gre samo za pridobivanje podatkov o zdravstveni ogroženosti sil, temveč za celovito pripravo pripadnikov, ki vključuje tudi pridobivanje podatkov o političnih, vojaških, ekonomskih, socialnih značilnostih ter infrastrukturi in 
informacijskem sistemu (PMESII) ${ }^{1}$. Prav tako je naloga MEDINT pridobivanje in analiziranje podatkov o geografskih, podnebnih in demografskih značilnostih z območij kriznega odzivanja.

Majhne države so na področjih obrambe in za zagotavljanje svoje varnosti razvile različne postopke. Odločitve, ki jih sprejemajo o nacionalni varnosti, zelo pogosto temeljijo na predhodnih izkušnjah. Zavedati se moramo, da majhnost države ne pomeni tudi njene šibkosti in da majhne države svojo »moč« uporabljajo drugače kot velike, saj jo izkazujejo kakovostno in ne količinsko (Mikuž, 2012). Značilnost majhnih držav je krepitev moči na različnih področjih, ki so za vsako državo zelo posebna. Pogosto se te države zaradi zmanjšanih zmogljivosti in sposobnosti na področju obrambe in varnosti povezujejo $\mathrm{z}$ drugimi državami $\mathrm{v}$ zavezništvo ali pa se odločijo za nevtralnost. Danes se v mednarodnem varnostnem okolju podpira večnacionalni razvoj zmogljivosti.

\section{POSLANSTVO IN NALOGE SLOVENSKE VOJSKE}

Zakon o obrambi (ZObr) določa poslanstvo in naloge SV. Slovenska vojska je bila leta 1994 v Zakonu o obrambi prvič imenovana kot obrambna sila RS. Nastala je iz takratne Teritorialne obrambe, katere naloge so bile omejene na nacionalno ozemlje. Danes SV poleg skrbi za nacionalno varnost opravlja naloge v mednarodnih operacijah in na misijah na kriznih žariščih zunaj geografskega območja zavezništva. Namen SV je z vojaškimi zmogljivostmi prispevati $\mathrm{k}$ uresničevanju interesov in nacionalnovarnostnih ciljev RS. Njeno poslanstvo je zagotavljati obrambne sposobnosti in izvajati vojaško obrambo Republike Slovenije, vojaško prispevati $\mathrm{k}$ mednarodnemu miru, varnosti in stabilnosti, sodelovati v sistemu varstva pred naravnimi in drugimi nesrečami ter podpirati druge državne organe in organizacije pri zagotavljanju varnosti.

Glavne naloge SV, ki izhajajo iz njenega poslanstva, so vzpostavitev načrtovanih zmogljivosti in vzdrževanje ustrezne stopnje njihove pripravljenosti, izvajanje nacionalne vojaške obrambe in izpolnjevanje mednarodnih vojaških zavez na podlagi 5. člena Severnoatlantske pogodbe. Med bistvene naloge SV spadata krepitev sodelovanja in zaupanja med SV ter vojskami zavezniških in prijateljskih držav ter uresničevanje interesov in nacionalnovarnostnih ciljev RS s sodelovanjem v MOM. Poleg naštetih nalog imajo bistven pomen tudi naloge zagotavljanja dvonamenskih zmogljivosti, sodelovanja pri zaščiti, reševanju in pomoči ob naravnih in drugih nesrečah ter podpora drugim državnim organom in organizacijam skladno z načrti, usposobljenostjo in opremljenostjo (Resolucija o splošnem dolgoročnem programu razvoja in opremljanja SV do leta 2025, 2010).

\footnotetext{
Angl. PMESII: Political, Military, Economic, Social, Infrastructure and Information.
} 


\subsection{Vloga Slovenske vojske v zavezništvu}

Slovenska vojska se je z vstopom Slovenije v Nato in Evropsko unijo (EU) zavezala $\mathrm{k}$ izpolnjevanju novih vlog in nalog predvsem pri zagotavljanju in ohranjanju mednarodnega miru, varnosti in stabilnosti. Kot pravi Vojaška doktrina (Furlan, 2006, str. 13), je Slovenija kot država članica prevzela odgovornost za skupno varnost. To med drugim zahteva skupno obrambno načrtovanje, sodelovanje pri oblikovanju skupnih odzivnih sil in njeno delovanje na kriznih območjih ter druge oblike vključevanja RS v dejavnosti zavezništva za zaščito stabilnosti severnoatlantskega območja in spoprijemanje z mednarodnim terorizmom ter drugimi nesimetričnimi grožnjami. Zavezništvo temelji na načelu, da je varnost vsake članice odvisna od varnosti vseh. To pomeni, da ogroženost ene članice vpliva na vse druge.

\subsection{Sodelovanje Slovenske vojske v mednarodnih operacijah in na misijah}

Slovenska vojska se spopada $\mathrm{z}$ izzivi in zahtevami za delovanje v MOM, med katerimi prevladujejo operacije v podporo miru. Kot navaja Likar (2009), je bilo prvo sodelovanje SV v operacijah kriznega odzivanja 14. maja 1997. V Albanijo je šlo na takratna krizna območja nekaj pripadnikov SV, med katerimi so bili tudi pripadniki zdravstvene enote (Role 1), ki so skrbeli za zdravstveno oskrbo sil ter evakuacijo poškodovancev.

Velikost slovenskih kontingentov (SVNKON) je zelo različna in se spreminja ter oblikuje glede na naloge in raven delovanja. Tako sta lahko za opravljanje nalog na strateški ravni ali za opravljanje nalog vojaškega opazovalca napotena le dva pripadnika, medtem ko lahko kontingent dosega večje število pripadnikov, tudi do 600 (Furlan v Grozde 2011, str. 34).

Predlog Obrambne strategije RS (2011, str. 2) opredeljuje sodelovanje SV predvsem v MOM znotraj Nata in EU, ki bolj neposredno vplivajo na nacionalno varnost. Tako so območja delovanja SV predvsem Jugovzhodna Evropa, Bližnji vzhod, Srednja Azija in Severna Afrika. Težišče sodelovanja je na območju Jugovzhodne Evrope, kjer ima RS zaradi geografske bližine ter zgodovinske povezanosti poleg varnostnih tudi politične, gospodarske, razvojne in druge interese ter možnosti za uporabo svojih primerjalnih prednosti v okvirih Nata in EU.

Pripadniki SV, ki so bili napoteni v MOM, so okolje, v katerem so delovali, poznali zelo različno - od poznanega do popolnoma nepoznanega. Pri tem opredeljujemo »okolje« kot širši pojem, pri čemer nas ne zanimajo samo geografske značilnosti neke države ali območja delovanja, temveč nas zanimajo tudi področja demografije ter zdravstvenih in socialnih razmer.

Za načrtovanje in vodenje operacij na transnacionalnih območjih delovanja so poleg geoprostorskih informacij pomembne informacije o zdravstvenih grožnjah, kot jih navaja Jurca (2006), med katere spadajo nalezljive bolezni, kontaminacija okolja, endemije, strupene rastline in živali ter težje mikroklimatske razmere. Avtorica 
sklepa na podlagi osebnih izkušanj, ki jih je pridobila v MOM, in glede na naravo dela, ki ga opravlja v odseku za laboratorijsko dejavnost v Vojaški zdravstveni enoti (VZE), da nepoznavanje in podcenjevanje zdravstvene ogroženosti lahko vodita $\mathrm{V}$ neustrezno preventivno zdravstveno načrtovanje ter nezadostno zdravstveno pripravo pripadnikov, kar se posledično lahko kaže z neuspešnostjo operacij na območju delovanja.

\section{PREOBLIKOVANJE OBVEŠČEVALNE DEJAVNOSTI}

Nove globalne grožnje in narava konfliktov, nova krizna žarišča in napredne tehnologije vodijo v nujnost sprememb v varnostnih sistemih in oboroženih silah. Odgovor na sodobne izzive je preoblikovanje vojaške organizacije iz funkcijske strukture v procesno, kar velja tudi za obveščevalno-varnostno dejavnost.

Obveščevalno-varnostna dejavnost se iz klasične ozke štabne organizirane dejavnosti s konceptom razvoja znanja reorganizira v centre znanja, v katerih se védenje in znanje zbirata, ob uporabi človeškega znanja in računalniških programskih orodij sistemsko analizirata ter posredujeta odločevalcem (Henigman in Rode, 2012, str. 84).

\subsection{Produktno osredotočen model obveščevalnega procesa}

Za funkcijsko ali klasično organizacijsko strukturo je značilno, da so pomembnejše navpične (vertikalne) povezave med posameznimi oddelki, med katerimi poteka zelo slaba komunikacija. Slaba stran funkcijske organizacije je, da poteka prek linije vodenja in poveljevanja, pri čemer mine veliko časa za zaprosilo, preverjanje, nadziranje in usklajevanje zahtevka za obveščevalno informacijo. Podatki in informacije so v zaprti arhitekturi ${ }^{2}$ v lasti obveščevalnih organov. Na voljo so samo izbranim naročnikom oziroma uporabnikom.

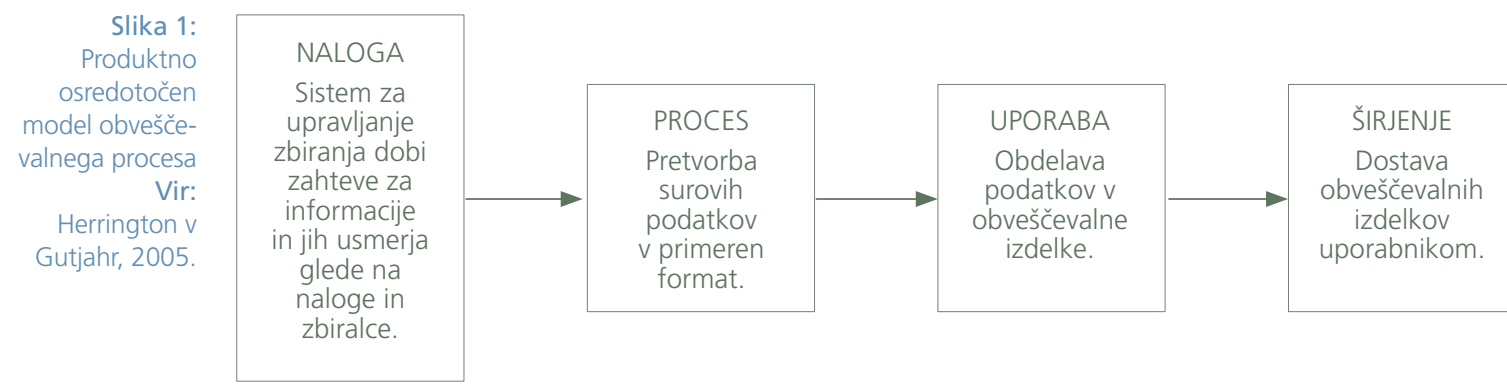

2 Produktno osredotočen model. 
»V funkcionalni oziroma klasični organizaciji so razmejene naloge in odgovornosti glede na organizacijski nivo, pri procesni organizaciji pa so naloge in odgovornosti vezane na celoten obveščevalni proces, ne glede na raven organiziranosti« (Šeme, 2012, str. 16).

\subsection{Uporabniško osredotočen model obveščevalnega procesa}

Procesna (horizontalna) organiziranost obveščevalno-varnostnega sistema vodi $\mathrm{k}$ racionalnejši, preglednejši in učinkovitejši obveščevalni zagotovitvi. Gre za celovito združevanje podatkov in informacij, ki bodo poveljnikom v procesu odločanja oziroma sprejemanja odločitev pravočasno in celovito (holistično) dostavljeni. Za doseganje koncepta procesne organiziranosti je nujna transformacija tradicionalnega produktno osredotočenega modela obveščevalnega procesa v uporabniško osredotočen model, ki predstavlja model prihodnosti.

Slika 2:

Uporabniško osredotočen model obveščevalnega procesa Vir: Herrington v Gutjahr, 2005.

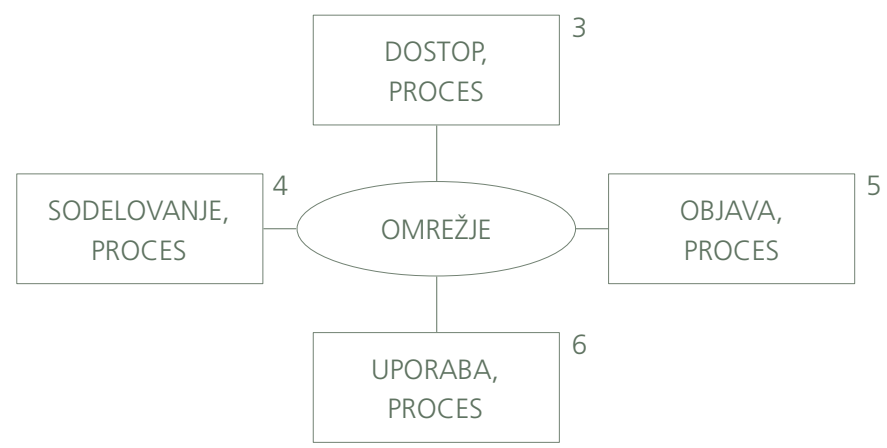

Kot navaja Šeme (2012, str. 18), je koncept »obveščevalne zbirke« eden izmed mogočih konceptov, iz katerega bi lahko dobili vzorec za organizacijo obveščevalne dejavnosti v SV. »Koncept uvaja pojem obveščevalne zbirke, ki odpira nove poglede na filozofijo obveščevalne dejavnosti predvsem na področjih shranjevanja, pregledovanja, načrtovanja in pridobivanja podatkov, funkcijskega, medresorskega in večnivojskega povezovanja s ciljem zagotoviti pravočasne in relevantne obveščevalne produkte, ki se navezujejo na vsebine in so v danem trenutku pomembni za naročnike obveščevalnih informacij.«

\footnotetext{
3 Sprotno zbiranje vseh relevantnih podatkov.

4 Zbiralci, obdelovalci in uporabniki pri zbiranju in obdelavi podatkov združujejo znanje.

5 Pooblaščenim uporabnikom omogočiti čim hitrejši dostop do podatkov.

- Obveščevalni podatki in informacije, katerih namen je dodana vrednost pri odločanju.
} 


\subsection{Obveščevalna dejavnost na področju zdravstva - MEDINT}

Obveščevalna dejavnost na področju zdravstva - MEDINT je bila v preteklosti nekoliko zapostavljena $\mathrm{v}$ primerjavi $\mathrm{z}$ razvojem in uporabnostjo obveščevalnih dejavnosti na drugih področjih. Za uveljavitev in izvajanje MEDINT je bilo treba zagotoviti tudi ustrezno kadrovsko podporo, predvsem strokovnjake s področja naravoslovnih ved.

Glavna naloga MEDINT je prepoznavanje groženj in pridobivanje podatkov s širšega geografskega območja o boleznih, ki ogrožajo zdravje ljudi in živali. Prepoznavanje okoljskih groženj je naloga strokovnjakov naravoslovnih ved, ki s svojim strokovnim znanjem posredujejo medicinske obveščevalne podatke glavni obveščevalni službi in tako pomagajo pri pripravi načrta za zdravstveno zaščito sile.

Zdravstvene podatke, ki so neomejeno dostopni po javnih virih, zbira osebje $\mathrm{z}$ ustrezno medicinsko izobrazbo. Pri tem bi se marsikdo vprašal, zakaj teh podatkov ne more zbirati osebje krovne obveščevalne dejavnosti. Razlog je $\mathrm{v}$ strokovnem znanju analitikov MEDINT, ki lahko pri ogledu zmogljivosti pridobijo izjemno pomembne podatke. V mednarodnih operacijah je med sodelujočimi nujna vsestranska in pospešena izmenjava teh podatkov. V sodobnem času, ko se vojaške operacije in misije izvajajo na ozemljih zunaj Natovega območja, je velika nevarnost zaradi izpostavljenosti zavezniških sil različnim dejavnikom tveganja za zdravje oziroma okoljskim grožnjam. Natov standard AJMedP-3 navaja (2008, str. 5-1), da ima okolje, poleg terorizma in orožja za množično uničevanje, pomembno vlogo pri združeni obveščevalni pripravi bojišča, saj so v njem različni škodljivi vplivi, ki zahtevajo posebno pozornost in so povezani z zemljepisnimi, vojaškimi, političnimi, kulturnimi in socialno-ekonomskimi vplivi.

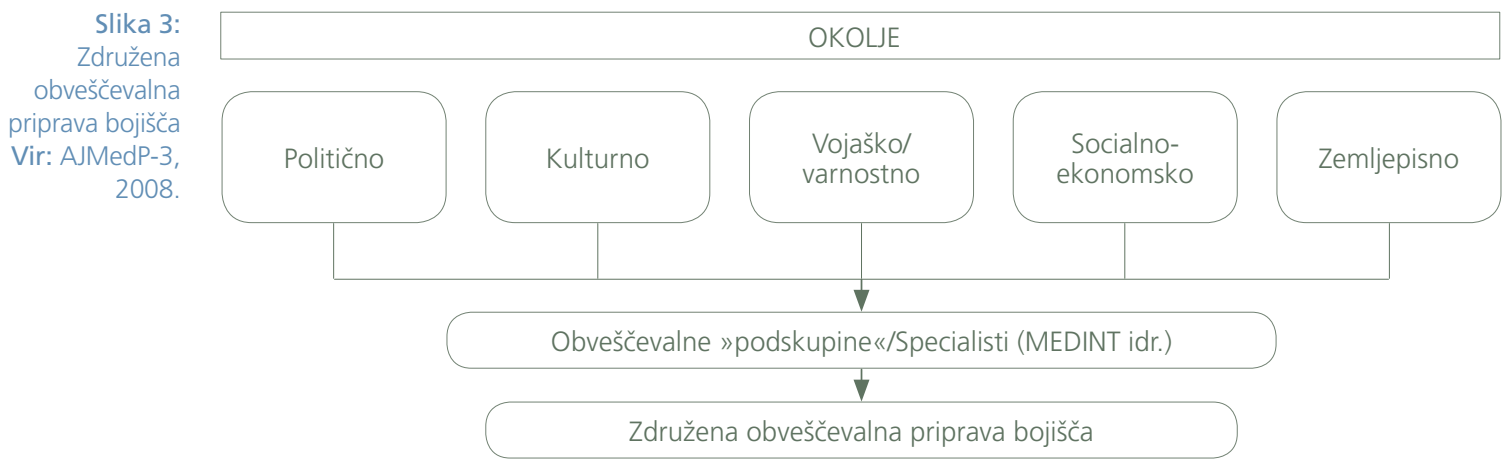


Strokovno zdravstveno osebje ima zelo pomembno vlogo, saj je odgovorno za zdravstveno pripravo sile, poleg tega pa mora zagotoviti obsežen program zdravstvene zaščite, ki temelji na pripravi načrta, ki podpira strateško, operativno in taktično raven operacije.

Za uspešen potek operacije je treba upoštevati dejavnike tveganja, ki škodljivo vplivajo na zdravstveno stanje sile. Ivanuša našteva nekaj kategorij (2012, str. 431) zahtevanih zdravstvenih podatkov, ki jih osebje MEDINT zbira in obdeluje ter posreduje uporabnikom.

Dejavniki okolja: Pripadniki, ki opravljajo naloge in operacije ekspedicijskega značaja, so na različnih geografskih območjih izpostavljeni številnim škodljivim vplivom, ki lahko bistveno vplivajo na njihovo sposobnost pri izvajanju nalog. Med dejavniki okolja, ki škodljivo vplivajo na zdravje ljudi, so kontaminacija tal, zraka, pitne vode in hrane ter prisotnost nekaterih strupenih rastlin in živali. Posebej je treba poudariti območja, na katerih je zaradi industrijskih emisij onesnaženost zraka zelo visoka. Med pomembne dejavnike okolja spadajo tudi težje mikroklimatske razmere.

Infekcijske bolezni: Najpogostejše nalezljive bolezni so tiste, ki jih povzročajo virusi in bakterije; glede na številčnost obolelih jih delimo na posamične, epidemije in pandemije. Kot ugotavlja Likar(2008, str.44), se v primerjavi s civilnim prebivalstvom za epidemijo šteje že 10 odstotkov obolelih vojakov v neki skupini. Posebnost so endemične bolezni, saj se pojavljajo na določenih območjih. Infekcijske bolezni s kratko inkubacijsko dobo omejujejo uspešnost operacije, medtem ko tiste z dolgo inkubacijo lahko povzročijo oslabitev premestljive sile in povzročijo obolevnost šele po vrnitvi v domače okolje.

Pri vojaško-civilnih zmogljivostih gre za zagotavljanje zdravstvenega varstva oboroženim silam in civilnemu prebivalstvu. Ivanuša poudarja (2012), da se ob naravnih nesrečah in v vojnih razmerah na podlagi organiziranosti, učinkovitosti in medsebojne podpore vojaško-civilnega zdravstvenega sistema določi učinkovitost zmogljivosti. Pri tem ne smemo spregledati še zmogljivosti in lokacij bolnišnic ter objektov primarnega zdravstva, saj se na podlagi teh podatkov odločimo, ali so zmogljivosti uporabne ali se jim je bolje izogniti.

»Jedrska, radiološka, kemična in biološka obramba - JRKBO in nova orožja: Podatki o narodni sposobnosti obrambe pred JRKB-agensi in novimi orožji ter njihov strateški in operativni vpliv na narodno ravnovesje so nesporno nujni« (Ivanuša, 2012, str. 432).

Zdravje črede oziroma jate in zmogljivosti veterinarske medicine: Gre za pridobivanje zdravstvenih podatkov širšega pomena, saj so uporabni pri načrtovanju in pri pripravi končnih mnenj. 
Naravoslovno znanje in biotehnologija: Z razvojem nove tehnologije, novega znanja in biotehnoloških postopkov so se uveljavile nove oblike zdravljenja, preizkušajo se nova cepiva in zdravila. Pri tem je treba upoštevati možnost tveganja dvojne uporabe, zato je treba dobiti podatke o novih tehnologijah, znanju in razvoju.

\section{VREDNOTENJE CELOVITE PRIPRAVE PRIPADNIKOV ZA MEDNARODNE OPERACIJE IN MISIJE}

Resolucija o splošnem dolgoročnem programu razvoja in opremljanja Slovenske vojske do leta 2025 (2010, str. 11) navaja, da se je v sodobnem mednarodnem varnostnem okolju verjetnost oboroženega meddržavnega izbruha zelo zmanjšala. $\mathrm{V}$ prihodnje bodo na mednarodno varnost vplivali predvsem neugodne naravne spremembe (podnebje), globalna finančna, demografska, socialna in gospodarska gibanja, omejenost naravnih in drugih strateških virov ter nenadzorovano trgovanje in storitve. Sodobne grožnje varnosti bodo hibridne grožnje, ki poleg konvencionalnih oblik vključujejo tudi terorizem, kriminal in neustaljene oblike delovanja, zlorabe informacijske tehnologije ter različnih gospodarskih in drugih dejavnosti.

Tudi v prihodnje bo SV sodelovala v večnacionalnem vojaškem okviru, v katerem bo delovala tako v konvencionalnih oblikah kot tudi proti hibridnim grožnjam. Kot pravi Grozde (2011, str. 71), bodo pri odzivanju SV na krizna žarišča imele prednost MOM na območjih Jugovzhodne Evrope, Bližnjega vzhoda, Srednje Azije in Afrike. Pripadnikom SV, ki opravljajo in bodo opravljali svoje poslanstvo na različnih geografskih območjih, je njihovo poznavanje PMESII z vidika geografskih in družbenih sistemov, z izjemo Zahodnega Balkana, slabo. Celovit pristop, ki temelji na poznavanju in razumevanju geografskega prostora in družbe kriznega območja, je zelo pomemben za ugotavljanje dejavnikov, ki vplivajo na uresničitev nalog, na prepoznavanje prednosti in slabosti ter tveganja lastnih sil kot tudi sil nasprotnika in drugih udeležencev. Pri napotitvi pripadnikov SV v MOM ima poleg celovite priprave operativnega okolja zelo pomembno vlogo ocena zdravstvenih in okoljskih virov ogrožanja.

Na podlagi intervjujev pripadnikov Vojaške zdravstvene enote, ki opravljajo svoje naloge v oddelku za preventivo, pripadnikov vojaške obveščevalne dejavnosti, pripadnika OVS (Obveščevalno varnostna služba) in poveljnikov kontingentov lahko predstavimo nekatere ugotovitve oziroma dejstva. OVS kot tudi drugi obveščevalno-varnostni organi v SV nimajo razvitih funkcionalnih obveščevalnih disciplin7, kar pomeni, da se v analize lahko vključijo strokovnjaki iz civilnega okolja ali posamezniki specialisti oziroma se informacije pridobijo prek javnih

\footnotetext{
Različna uporaba terminov za načine pridobivanja obveščevalnih podatkov.1. Pridobivanje obveščevalnih podatkov se izvaja z obveščevalnimi disciplinami (http://www.fvv.uni-mb.si/dv2008/zbornik/clanki/GrozdeHenigman.pdf). 2. D. Črnčec V knjigi Obveščevalna dejavnost v informacijski dobi (2009) uporablja termin zvrsti za načine pridobivanja podatkov na obveščevalnem področju. Terminologija ni enotna; kateri izraz oziroma termin je ustreznejši/pravilnejši odpira novo poglavje razprave.
} 
virov $^{8}$. Na podlagi sklenjenih dvostranskih državnih sporazumov se informacije lahko pridobivajo tudi pri partnerskih službah in vojskah.

Po pridobljenih podatkih so pripadniki med pripravami za odhod v MOM precej slabo seznanjeni s podatki, ki se nanašajo na dejavnike tveganja oziroma na oceno tveganja za zdravje. Vedeti moramo, da je geografska razpršenost mednarodnih operacij in misij, v katerih trenutno sodeluje tudi SV, velika, predvsem pa je treba pri dejavnikih tveganja za zdravje razlikovati med operacijo, ki poteka na Balkanu, in tisto v tropski Afriki. Po pripovedovanju pripadnikov imajo ti o cepljenju in antimalarikih zelo različna mnenja. To kaže na dejstvo, da v programu priprav pripadnikov na MOM manjka zelo pomembno področje, ki ga imenujemo medicinska geografija.

V prihodnje se bo SV soočila z izzivi in zahtevami za delovanje v mednarodnih operacijah in na misijah predvsem na ozemljih, na katerih bo izpostavljena različnim boleznim oziroma zdravstvenim grožnjam, ki jih v domačem okolju ni. Te vrste groženj povečujejo zaskrbljenost in zahtevajo učinkovito preventivno delovanje. Za tako zagotovitev je najpomembnejša vzpostavitev medicinske obveščevalne dejavnosti, ki zaradi svojega poslanstva zahteva poleg obveščevalnega osebja tudi osebje z različnim drugim znanjem in obvladovanjem naravoslovnega znanja.

Da bi se izognili nadaljnjemu neučinkovitemu sistemu delovanja, katerega naloga je oceniti geografska in zdravstvena tveganja, ki bi jim bile zavezniške sile lahko izpostavljene, analizirati zdravstvene zmogljivosti in sposobnosti na območju delovanja ter izdelati analize groženj, predstavljamo predlog modela MEDINT v SV. Predlog temelji na modelu, ki ga je predlagal in opisal Grozde (2011) na procesu geoprostorske obveščevalne podpore SV za MOM.

Celovita priprava operativnega okolja v našem modelu vključuje tudi vrednotenje obveščevalnih podatkov s področja zdravstva, ki neizhajajo le iz ciljnega geografskega prostora, temveč tudi iz transnacionalnega prostora. $\mathrm{V}$ tabeli 1 je prikazan predlagan izpopolnjen in nekoliko prirejen proces obveščevalnega vrednotenja geografskega prostora, saj smo v posamezne stopnje dodali sodelovanje medicinske geografske obveščevalne podpore. Proces je razdeljen na štiri dele, ki se naprej delijo na različno število časovnih stopenj. Model predstavlja vključevanje posameznih služb znotraj MO RS (Ministrstvo za obrambo RS) na vseh štirih stopnjah napotitve v MOM.

$\mathrm{Na}$ vseh štirih stopnjah napotitve se začnejo izvajati in dodeljevati naloge na posameznih ravneh. Bistvena sta prepoznavanje in ocena okoljskih in zdravstvenih virov ogrožanja, ki bi jim lahko bile izpostavljene sile SV.

$\&$ Open Source Intelligence (OSINT). 
Tabela 1: Proces medicinskogeografskega vrednotenja prostora napotitve po stopnjah Vir: Grozde, 2011.

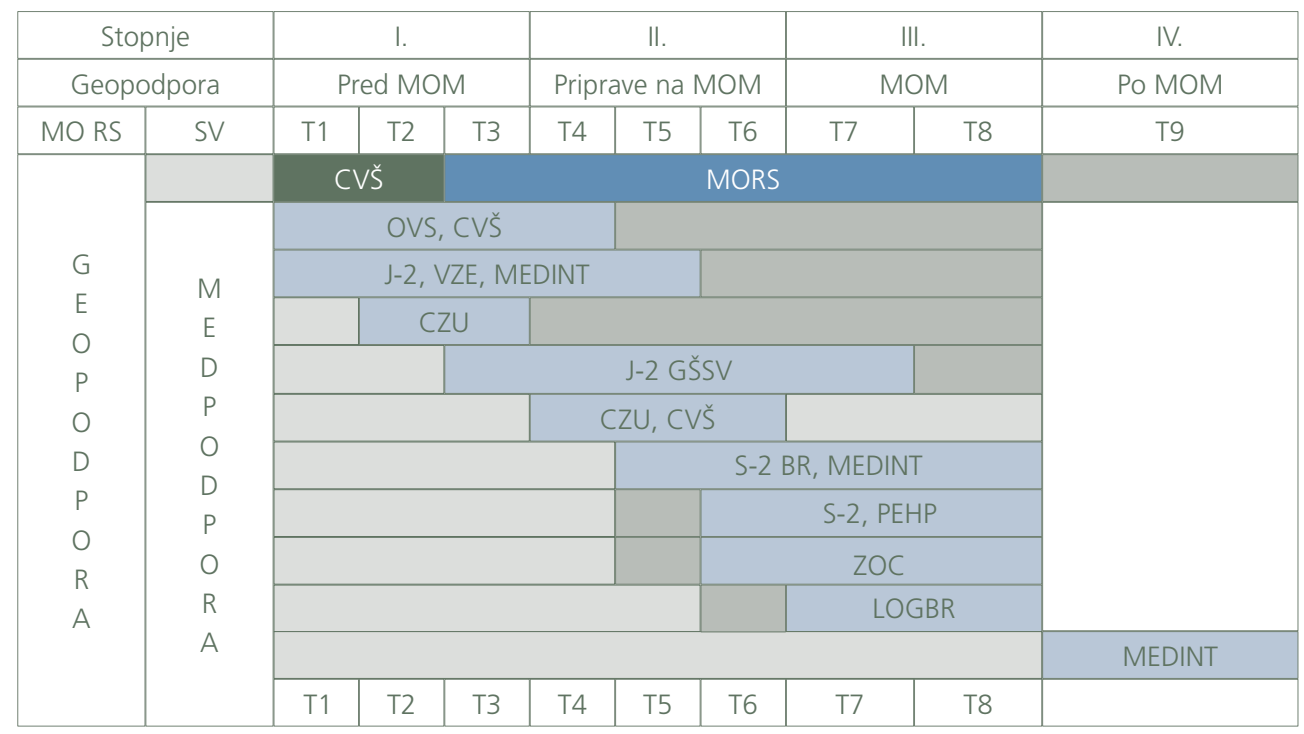

Legenda:

\begin{tabular}{|l|l|}
\hline Sodeluje \\
\hline Sodeluje po potrebi \\
Geoprostorski podatki in informacije \\
Javni viri \\
Ne sodeluje
\end{tabular}

\section{I. stopnja: Pred angažiranjem SV v MOM}

\section{T1: Dokumentarna obveščevalna dejavnost}

Opravi se celovita analiza okolja kriznega žarišča, v katero so vključeni zgodovinska dogajanja, geografske značilnosti geoprostora ter zdravstvena problematika. V tem procesu sodelujejo GŠSV ${ }^{9}, \mathrm{CVS}^{10}$ in OVS, ki izdelajo celovito pripravo operativnega okolja. Na prvi stopnji manjka najpomembnejši del, to je MEDINT, ki naj bi v okviru S-2 VZE ali J-2 ${ }^{11}$ GŠSV opravil poizvedovanje o zdravstvenih in okoljskih virih ogrožanja.

\footnotetext{
9 Generalštab Slovenske vojske.

${ }^{10}$ Center vojaških šol.

"Sektor za obveščevalne zadeve.
} 


\section{T2: Situacijska obveščevalna dejavnost}

Situacijska obveščevalna dejavnost se začne takrat, ko neko območje postane interesno območje zavezništva. V tem procesu sodelujejo OVS, J-2, MO, GEOpodpora, CZU ${ }^{12}$ in MEDINT S-2 VZE/J-2 GŠSV.

T3: V tretji točki prve stopnje se opravi analiza stanja in se zberejo obveščevalni produkti območja. Ob prvi napotitvi na povsem novo območje delovanja SV naj se osebje MEDINT posvetuje s strokovnjaki različnih naravoslovnih področij. Na podlagi pridobljenih podatkov in $\mathrm{v}$ sodelovanju $\mathrm{z}$ nacionalnimi naravoslovnimi ustanovami ter članicami zavezništva naj bi strokovno osebje MEDINT pripravilo analizo začetne presoje groženj in zdravstvenih zmogljivosti ter sposobnosti na območju delovanja. Pripraviti je treba načrt in obseg cepljenja kot preventivnega ukrepa za preprečevanje in obvladovanje nalezljivih bolezni.

\section{II. stopnja: Priprave na MOM}

T4: CZU/CVŠ začne priprave s postavitvijo simulacijskega modela, pri tem aktivno sodelujeta OVS in J-2.

T5: Vključitev enote oziroma izbranega bataljona, katerega sile bodo opravljale naloge v MOM. Proces obsega ogled interesnega območja. OVS preda analize J-2, GEO-podpora MO pa preda bazo UDIGISP ${ }^{13}$ in GEO-portalu. Ciljno zdravstveno osebje MEDINT naj bo vključeno v kratke analize misije in začetne presoje groženj. Po ogledu interesnega območja in pridobljenih podatkih o zdravstvenih in okoljskih grožnjah bi bilo treba oceniti tveganje ter pripraviti epidemiološko poročilo.

T6: Zadnja točka druge stopnje je namenjena usposabljanju, pripravam in preverjanju pripravljenosti pripadnikov v MOM. Pri tem sodeluje GŠSV, in sicer J-2, CVŠ in CZU. V zdravstvenem centru VZE se izvajajo preventivni zdravniški pregledi, ki obsegajo razširjen obseg preiskav. Glede na izvide preiskav se ugotovi zdravstvena sposobnost oziroma nesposobnost pripadnikov za opravljanje nalog na območjih zunaj tradicionalnih meja. Tudi $\mathrm{v}$ tem procesu bi moralo sodelovati strokovno osebje MEDINT, ki bi s svojim strokovnim predavanjem ozaveščalo pripadnike o zdravstvenih grožnjah in ukrepih za zaščito lastnih sil.

\section{III. stopnja: MOM}

T7: Oborožene sile SV opravljajo naloge skladno z navodili nadrejenega poveljstva. J-2 in S-2 brigade aktivno sodelujeta s silami v MOM, prav tako logistična brigada zagotavlja logistično podporo. OVS in J-2 sodelujeta, če je treba, medtem ko CVŠ na tej stopnji nima naloge. Če se zgodijo spremembe na območjih delovanja, morajo enote posredovati informacijo v matično okolje.

\footnotetext{
12 Center za združeno usposabljanje.

${ }^{13}$ Upravljanje in distribucija GIS-podatkov.
} 
T8: S-2 brigade in bataljona aktivno sodelujejo pri podpori vojaške aktivnosti. J-2 in OVS sodelujeta, če je treba. Pri obeh točkah tretje stopnje naj bi sodeloval tudi MEDINT. Gre za spremljanje zdravstvene situacije sile na območju delovanja, spremljanje izbruhov oziroma okoljskih in zdravstvenih groženj ter posredovanje informacij poveljniku kontingenta.

\section{IV. stopnja: Po vrnitvi iz MOM}

T9: Na tej stopnji sodelujoči pripadniki obveščevalne dejavnosti naredijo analizo opravljene naloge. CVŠ predlaga načelniku GŠSV uvajanje primerov dobre prakse in odpravo zaznanih pomanjkljivosti. Ugotovljene spremembe na področju geoprostora in geoinformacij $\mathrm{v}$ operativnem okolju $\mathrm{J}-2 \mathrm{v}$ sodelovanju $\mathrm{z}$ OVS predajo GEO-podpori MO, ki jo vnese $\mathrm{v}$ UDiGISP in centralno geoprostorsko bazo geoportala MO. Dostop do baze je urejen z akti vodenja in poveljevanja. Vsi pripadniki se po vrnitvi iz MOM udeležijo zdravniškega pregleda z razširjenim obsegom laboratorijskih preiskav. Slika 4 prikazuje vključevanje obveščevalnega ciklusa MEDINT v obveščevalni ciklus krovne obveščevalne dejavnosti ter stalno povezavo med MEDINT in zdravstvenim sistemom. MEDINT na prvi in drugi časovni stopnji zagotavlja najpomembnejše podatke za zdravstveno zaščito sile. Končni obveščevalni proizvod, ki vključuje oceno zdravstvene ogroženosti, je glavni proizvod MEDINT, in sicer kot odgovor na poveljnikove zahteve.

\subsection{Organizacija in delovanje vojaškega zdravstva na primeru majhnih držav}

\subsubsection{Republika Hrvaška}

Vojaško zdravstvo Republike Hrvaške je v organizacijski strukturi del logističnomedicinskega podpornega sistema. Kot je navedeno v Almanac of Medical Corps Wordwide (2013), ima Hrvaška tako imenovani integriran nacionalni sistem zdravstvenega varstva $\mathrm{z}$ izjemo Role 1, katerega zmogljivosti pokriva vojaška zdravstvena služba. Kadar je zahtevana višja raven upravljanja zdravstvenih zmogljivosti, to vlogo prevzamejo civilne zdravstvene strukture. Celovita zdravstvena podpora v oboroženih silah Hrvaške je organizirana in usklajena kot poseben funkcionalni sistem, ki temelji na doktrinarnih dokumentih Nata, ki so skladni z zahtevanimi nacionalnimi predpisi. Hrvaška nima vojaške bolnišnice, zato je Vojaški zdravstveni center glavni vojaški objekt v Oboroženih silah Hrvaške, ki je odgovoren za primarno in preventivno zdravstveno varstvo ter veterinarsko medicino. V organizacijsko strukturo spadajo Oddelek za primarno zdravstveno varstvo, Oddelek za veterino, Oddelek preventivne medicine, Poveljstvo Role 2 ter dva inštituta, in sicer Inštitut zračne medicine in Inštitut pomorske medicine.

\subsubsection{Slovaška republika}

Naloga, ki jo opravlja zdravstvena služba Slovaške, je zagotavljanje temeljne zdravstvene oskrbe in specialistične diagnostike, namenjene pripadnikom Slovaške vojske, nekdanjim vojakom in njihovim sorodnikom. V Almanac of Medical Corps Wordwide (2013) Slovaška predstavlja organizacijsko strukturo, v kateri je poveljnik 
oziroma strokovni vodja osrednji organ vojaške zdravstvene dejavnosti (enote) oboroženih sil Slovaške. Bolnišnica v Ružomberoku je največja vojaška bolnišnica na ozemlju Slovaške. Ustanovljena je bila leta 1994 kot vojaška bolnišnica Ružomberok in se je še istega leta preimenovala v Centralno vojaško bolnišnico Ružomberok.

\subsubsection{Irska}

Glavno poslanstvo vojaškega zdravstva (Medical Corps) v oboroženih silah Irske je zagotavljanje zdravstvene podpore, preprečevanje bolezni med pripadniki in dobra zdravstvena pripravljenost pripadnikov, nujna za opravljanje aktivnosti doma in v tujini. Vojaška bolnišnica St. Bricins Military Hospital je v Dublinu in zagotavlja tako bolnišnično kot ambulantno oskrbo. Poleg tega se v njej izvajata radiološka in laboratorijska diagnostika. V okviru vojaškega zdravstva potekajo usposabljanja s področja zdravstvene tematike, ki se jih udeležujejo zdravstveno osebje in drugi pripadniki. Pripadniki vojaškega zdravstva se udeležujejo vseh večjih mednarodnih operacij in misij, na katerih opravljajo pomembne naloge pri zdravstveni in zobozdravstveni podpori. V civilno-vojaškem sodelovanju vojaško zdravstvo izpolnjuje pomembno vlogo pri izvajanju humanitarne pomoči civilnemu prebivalstvu (Almanac, 2013).

»Po pridobitvi podatkov, tudi zelo skopih, glede organizacije in delovanja vojaškega zdravstvenega sistema na primeru nekaterih majhnih evropskih držav, lahko rečemo, da je osnovno poslanstvo primerljivo s poslanstvom Vojaške zdravstvene službe SV. Do razlikovanj prihaja v zdravstvenih zmogljivostih in vojaških zdravstvenih objektih; npr. vojaške bolnišnice, ki jih nekatere zgoraj primerljive države imajo, druge pa jih nimajo. Podatkov glede upravljanja MEDINT zgoraj omenjenih držav nismo uspeli pridobiti, razen za Republiko Hrvaško, ki omenja, da za celovito zdravstveno podporo oboroženih sil Hrvaške poleg nacionalnih predpisov uporablja tudi Natovo doktrino« (Kremžar, 2014, str. 44).

\subsection{Obveščevalni ciklus MEDINT}

Slika 4 prikazuje vlogo MEDINT v razmerju med zdravstvenim sistemom in krovno obveščevalno dejavnostjo. Zbiranje zdravstvenih podatkov mora postati naloga izključno odgovornega in predanega zdravstvenega osebja MEDINT, saj na primer pri ogledu interesnega območja njegovi analitiki pridobijo veliko pomembnih podatkov, ki bi si jih osebje brez strokovnega znanja razložilo povsem drugače. Kot poudarja Ivanuša (2012), se podatki o oceni okoljskih in zdravstvenih virov ogrožanja, o analizi zdravstvenih zmogljivosti in sposobnostih na območju delovanja morajo vključiti v obrazec, ki ga predpisuje STANAG $2481^{14}$. Na podlagi povzetka MEDINT je treba pripraviti osnutek in operacijski načrt zdravstvene podpore sile. Poleg tega je treba skladno z usmeritvami pripraviti strokovno epidemiološko poročilo.

Pomanjkanje strokovnega zdravstvenega osebja v obveščevalnih službah se kaže tudi v tem, da ima osebje obveščevalne dejavnosti težave oziroma premalo znanja o

${ }^{14}$ Medical Information Collection and Reporting. 
Slika 4: Vloga MEDINT v razmerju med zdravstvenim sistemom in krovno obveščevalno dejavnostjo Vir: Ivanuša, 2012.

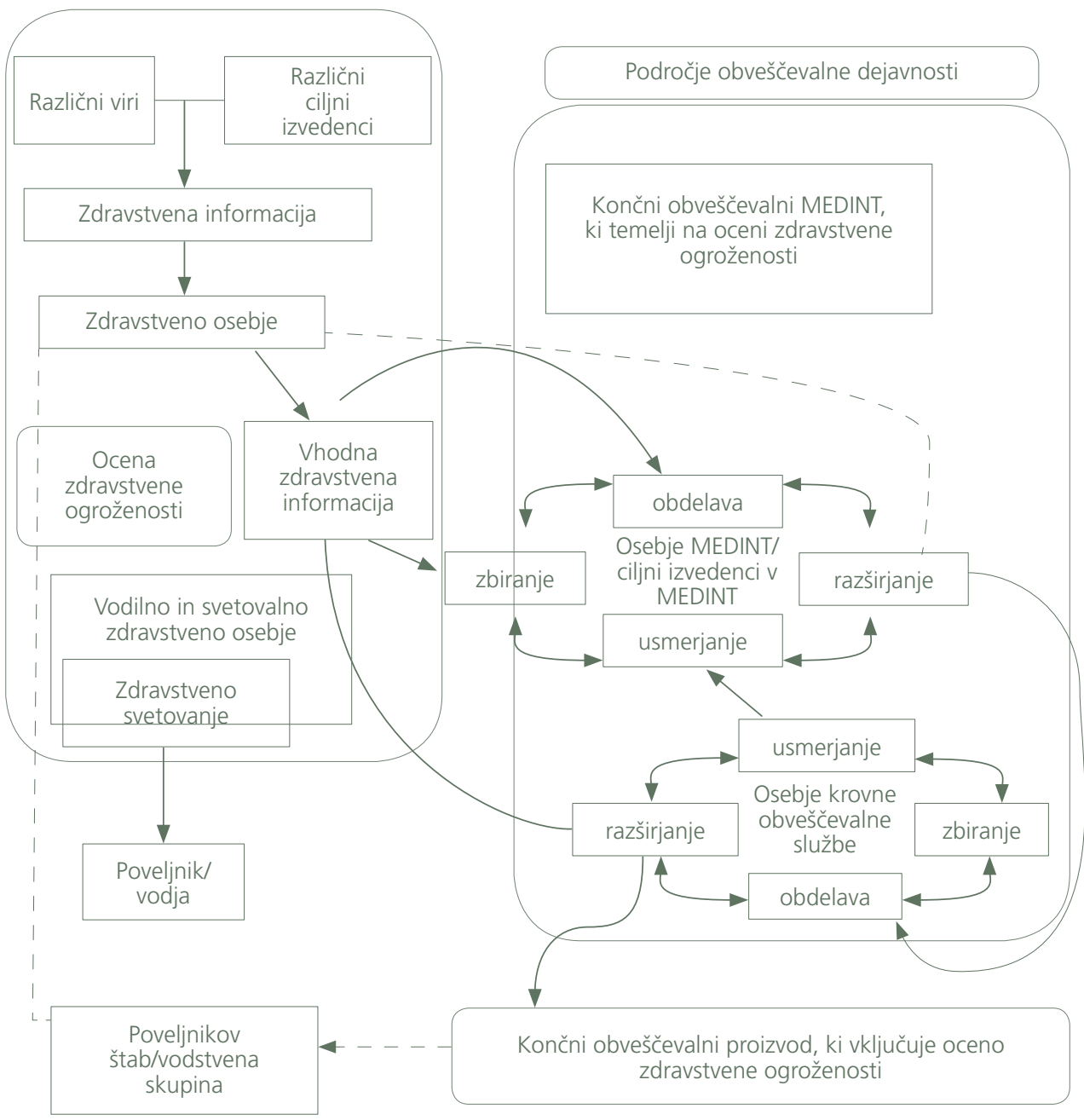

zahtevanju zdravstvenih podatkov. Da je sodelovanje med obveščevalno dejavnostjo, strokovnim zdravstvenim osebjem MEDINT in zunanjim zdravstvenim sistemom nujno, je razvidno že iz prve stopnje obveščevalnega ciklusa MEDINT. Usmerjanje kot njegova prva stopnja je namenjeno načrtovanju in zbiranju zdravstvenih podatkov. Usmerjanje lahko odredi poveljnik ali pa ga osebju krovne obveščevalne dejavnosti predlagajo strokovno osebje MEDINT in strokovnjaki zdravstvenih služb. Druga stopnja obveščevalnega ciklusa je zbiranje zdravstvenih podatkov z uporabo ciljnih strokovnih virov. Kot navaja Ivanuša (2012), moramo biti na tej stopnji posebno pozorni na pravočasno posredovanje zbranih zdravstvenih podatkov na stopnjo obdelave, saj se lahko zgodi, da ti podatki med zbiranjem na območju MEDINT hitro zastarajo, predvsem ko gre za podatke o bioloških agensih. Na stopnji obdelave 
se obveščevalni podatki pridobivajo s primerjanjem, vrednotenjem, analiziranjem in združevanjem podatkov. Gre za presojo zanesljivosti vira in resničnosti podatka. $\mathrm{Na}$ tej stopnji se zdravstveni podatki, zbrani kot odziv usmeritve poveljnika, spremenijo v medicinske obveščevalne podatke. Zadnja stopnja ciklusa MEDINT je razširjanje, ki temelji na pravočasnosti prenosa proizvodov MEDINT obveščevalnemu osebju, ki prevzame odgovornost nadaljnjega razširjanja obveščevalnih informacij.

Menimo, da bi strokovno osebje MEDINT moralo za vsako geografsko območje, na katerem pripadniki SV opravljajo naloge v podporo miru, pripraviti bazo oziroma knjižnico podatkov o boleznih in drugih okoljskih dejavnikih tveganja, ki vplivajo na zdravje ljudi in živali. Ti podatki bi bili seveda klasificirani, saj bi med obdelavo v obveščevalnem ciklu pridobili vrednost medicinsko-obveščevalnega podatka. Tako bi baza podatkov vsebovala seznam bolezni in bi bila na voljo za ogled tako osebju MEDINT kot osebju obveščevalne dejavnosti.

Sklep Slovenska vojska se poleg nalog nacionalne obrambe spopada z izzivi in zahtevami za delovanje $\mathrm{v}$ mednarodnih operacijah in na misijah v okoljih velike geografske razpršenosti in v težkih podnebnih razmerah. Republika Slovenja se s članstvom v EU in Natu zavzema za zagotavljanje in ohranjanje mednarodnega miru, varnosti in stabilnosti. V mednarodnem varnostnem okolju, v katerem delujejo oborožene sile zavezništva, so poleg novih oblik ogrožanja varnosti, tako imenovanih hibridnih groženj, kot vir ogrožanja vedno bolj izraženi podnebne spremembe, naravne in druge nesreče ter različni učinki globalizacije. Zelo pomemben vir ogrožanja, predvsem v okoljih zunaj Natovega območja, ki so jim oziroma jim bodo sile zavezništva izpostavljene, so različne bolezni, ki jih v matičnem okolju ni.

Vojaška obveščevalna dejavnost SV v sodelovanju z OVS omogoča celovito obveščevalno-varnostno podporo pripadnikom SV V MOM. Pravočasno zagotavljanje obveščevalno-varnostnih podatkov omogoča poveljniku podporo pri sprejemanju odločitev in pripravi načrta za zaščito lastnih sil. Geografska razpršenost mednarodnih operacij in misij, predvsem na ozemljih Srednje in Severne Afrike, zahteva zagotavljanje učinkovite obveščevalno-varnostne podpore pripadnikom $\mathrm{SV}$, ki pa je obrambni sistem v celoti ne more zagotoviti, zato se povezuje s tujimi obveščevalnimi službami. Tako se pridobijo podatki, ki obsegajo tudi analizo nasprotnikovih družbenih sistemov PMESII in se uporabijo v pripravah pripadnikov SV v MOM.

SV in sile zavezništva delujejo na območjih, ki so zaradi posledic vojnih razmer doživela izrazito poslabšanje tako na področjih socialne in zdravstvene varnosti kot na področjih gospodarskih, ekonomskih in političnih sistemov. Poškodovana ali uničena infrastruktura in slabe higienske razmere so pogosto vzrok onesnaženosti tal, pitne vode ter izbruhov alimentarnih toksikoinfekcij.

Izpostavljenost različnim zdravstvenim in okoljskim grožnjam se povečuje z večjo geografsko oddaljenostjo od matičnega okolja. Z izjemo Balkana, ki ga ne smemo 
zanemarjati, ko govorimo o dejavnikih tveganja za zdravje, saj se na tem ozemlju še vedno pojavljajo izbruhi nove gripe, so pričakovanja in zaskrbljenost pripadnikov zaradi zdravstvene zaščite večja ob njihovi napotitvi na območja Bližnjega vzhoda, Afrike in Azije.

V procesu medicinsko-geografskega vrednotenja prostora se pri obveščevalni pripravi bojišča oziroma prostora dajejo mnenja in delajo analize (zgodovinske, geografske, politične, vojaške, socialne, ekonomske, itd.) o kriznih žariščih, torej o območjih, ki zanimajo RS za sodelovanje. Pri celoviti obveščevalni pripravi bojišča oziroma prostora bi moral pomagati organ, ki v sestavi strokovnjakov različnih naravoslovnih ved daje mnenje o zdravstveni zaščiti sil (predlog modela). Za tako delovanje je treba uvesti program oziroma dejavnost, ki bo omogočala zagotavljanje zdravstvene zaščite sile pred in med operacijami ter po njih. Obveščevalna dejavnost na področju zdravstva se ukvarja z zbiranjem medicinskih, bioznanstvenih, epidemioloških, okoljskih in drugih podatkov, ki se kakor koli nanašajo na zdravje ljudi in živali.

Ravno zato MEDINT za uspešno delovanje potrebuje v svojem krogu strokovnjake različnih naravoslovnih smeri (zdravnik, biolog, veterinar idr.), ki bi bili dodatno usposobljeni za področja obveščevalnih dejavnosti in bi strokovno ter predano opravljali svoje delo.

Glede na trenutne razmere pri pripravah pripadnikov na MOM in po informacijah, ki smo jih dobili z intervjuji, lahko rečemo, da je zagotavljanje zdravstvene zaščite zavezniških sil učinkovito pri vzpostavitvi strokovne skupine za MEDINT in izvajanju njegovega programa $\mathrm{v}$ sodelovanju $\mathrm{z}$ osebjem obveščevalne dejavnosti znotraj MO ter z nacionalnimi zdravstvenimi ustanovami.

1. Bandekow, L., 2013. Almanac of Medical Corps Worldwide 44-45, Nemčija, str. 8990,140-143.

2. Črnčec, D., 2009. Obveščevalna dejavnost v informacijski dobi. Ljubljana: Defensor.

3. Furlan, B., Rečnik, D., Vrabič, R., Marǎ̌, V., Cerkovnik, J., Špur, B., Šonc, M., Tušak, M., Ivanuša, M., Gorjup, B., Kojadin Lasič, U., Unger, M., 2006. Vojaška doktrina. Ljubljana: Defensor:

4. Grozde, J., 2012. V Geoprostorska podpora obrambnemu sistemu Republike Slovenije. Geoprostorska obveščevalna podpora Slovenski vojski v pripravah na mednarodne operacije in misije. Ministrstvo za obrambo RS. Geodetski inštitut Slovenije. ZRC SAZU. Ljubljana: MO RS, str. 135-150.

5. Grozde, J., 2011. Obveščevalno vrednotenje geografskega prostora območij delovanj Slovenske vojske (Zaključna naloga). Maribor: Poveljniško-štabna šola.

6. Gutjahr, M. H., 2005. The Intelligence Archipelago: The Community's Struggle to Reform in the Globalized Era. The Joint Military Intelligence College.

7. Henigman, Ž., in Rode, A., 2012. Smernice razvoja obveščevalno-varnostne dejavnosti 21. stoletja. Bilten Slovenske vojske. Znanstveno- strokovna publikacija SV, 14(1), str. 69-84.

8. Ivanuša, T., 2012. Obveščevalno-varnostna dejavnost: Procesi, metode, nadzor. VI. Podbregar (ur.), Obveščevalna dejavnost na področju zdravstva - MEDINT. Znanstvena monografija. Ljubljana: Fakulteta za varnostne vede. 
9. Jurca, I., 2006. Vključevanje civilnih zmogljivosti v operacije v podporo miru. $V$ Pipenbaher, B. (ur). Zdravstvene razmere na območju operacij v podporo miru in preventivni ukrepi Ljubljana: Ministrstvo za obrambo, Direktorat za obrambne zadeve, Sektor za civilno obrambo, str. 185-192.

10. Kremžar Kovač, T., 2014. Izvajanje vojaško medicinske obveščevalne dejavnosti z omejenimi viri na primeru majhnih držav. (Magistrsko delo). Ljubljana: Fakulteta za varnostne vede.

11. Likar, S., 2009. Obveščevalno-medicinski podatki v Slovenski vojski. (Diplomsko delo). Ljubljana: Fakulteta za varnostne vede.

12. Mikuž, I., 2012. Strategy Research Project International Fellow. Influence Small State Force Design. United States Army War College.

13. NATO Standardization Agency, 2008. Allied Joint Medical Doctrine for Medical Intelligence (MEDINT) - AJMedP-3. Brussels: NATO Standardization Agency.

14. Resolucija o splošnem dolgoročnem programu opremljanja in razvoja Slovenske vojske do leta 2025 (ReSDPRO), 2010. Uradni list RS, 99/10.

15. Sunzi (2009). Umetnost vojne. Mladinska knjiga Založba,d,d, Ljubljana.

16. Šeme, R., 2012. Učinkovita obveščevalna zagotovitev v Slovenski vojski (Zaključna naloga). Maribor: Poveljniško-štabna šola.

17. Zakon o obrambi, 2004. Uradni list RS, 103/04.

18. Zakon o službi v Slovenski vojski, 2007. Uradni list RS, 68/07. 